\title{
Aplikasi Prinsip Animasi Exaggeration, Kemahiran Berfikir Kritis dan Kreatif serta Model Motivasi ARCS Terhadap Topik Integer Matematik Tingkatan Satu
}

\author{
Application of Animation Principle of Exaggeration, Creative and Critical Thinking \\ Skills and ARCS Motivation Model in Form 1 Mathematics Integer Topic
}

\author{
Aizu Khalili Zohedi ${ }^{1}$, Nor Hasbiah Ubaidullah ${ }^{2}$, Norasikin Fabil ${ }^{3}$ \\ ${ }^{I}$ Faculty of Art, Computing \& Creative Industry, Universiti Pendidikan Sultan Idris; aizukhalili@gmail.com \\ ${ }^{2}$ Faculty of Art, Computing \& Creative Industry, Universiti Pendidikan Sultan Idris; hasbiah@fskik.upsi.edu.my \\ ${ }^{3}$ Faculty of Science and Technology, Universiti Sains Islam Malaysia; norasikin.fabil@usim.edu.my
}

\begin{abstract}
Abstrak
Kajian menunjukkan pelajar mempunyai masalah dalam mempelajari topik Integer Matematik Tingkatan 1. Ini menyebabkan pelajar mempunyai motivasi yang rendah dalam pembelajaran. Pelajar memerlukan sokongan tambahan dan motivasi agar mereka dapat belajar lebih baik dan bermotivasi. Kertas kerja ini bertujuan untuk mengkaji aplikasi prinsip animasi exaggeration, kemahiran berfikir kritis dan kreatif serta elemen motivasi terhadap topik Integer Matematik Tingkatan 1. Kertas kerja ini memfokus kepada aspek kemahiran berfikir kritis dan kreatif yang perlu dikuasai, model motivasi ARCS dan prinsip exaggeration dalam animasi iaitu elemen penting yang menyumbang kepada kerangka konseptual kajian.
\end{abstract}

Kata kunci: Exaggeration, kemahiran berfikir kritis dan kreatif, model motivasi ARCS, kerangka konseptual kajian.

\begin{abstract}
Studies show that students have problems in studying Form 1 Mathematics Integer topic. This causes students to have low motivation in learning. Students need additional support and motivation so that they can learn better and be motivated. This paper aims to examine the application of exaggeration principles in animation, critical and creative thinking skills and motivational element in Form 1 Mathematics Integer topic. This paper focuses on aspects of critical and creative thinking skills to be mastered, ARCS motivation model and the principles of exaggeration in animation as an important element that contributes to the conceptual framework.
\end{abstract}

Keywords: Exaggeration, critical and creative thinking skills, ARCS motivational model, conceptual framework. 


\section{PENGENALAN}

Banyak rungutan daripada pelbagai pihak terhadap penguasaan Matematik dalam kalangan pelajar di negara ini. Guru-guru Matematik kerap menghadapi masalah dalam pengajaran dan pembelajaran $(\mathrm{P} \& \mathrm{P})$ kerana pelajar sukar memahami konsep tentang sesuatu isi pelajaran yang disampaikan. Ini disebabkan pelajar mempunyai motivasi yang rendah dan tidak memberi tumpuan kerana beranggapan Matematik adalah mata pelajaran yang sukar dikuasai. Oleh yang demikian adalah penting bagi guru mempelbagaikan strategi pengajaran terutamanya penggunaan komputer bagi membolehkan pelajar menguasai konsep dan kemahiran dalam Matematik.

\section{PERNYATAAN MASALAH}

Kajian yang dilakukan oleh KPM mendapati Malaysia berada pada kedudukan sepertiga terbawah dalam kalangan 74 negara yang ditaksir dalam 2009+ Programme for International Student Assessment (PISA) dalam Matematik, Sains, dan Bacaan (KPM, 2013). Malaysia berada di kedudukan ke 57 bagi mata pelajaran Matematik. Peratus murid yang tidak mencapai tanda aras yang ditetapkan semakin besar dan murid tidak mencapai standard minimum dalam The International Trends in Mathematics and Science Study (TIMSS). Ini dapat dilihat dalam peningkatan peratusan murid yang tidak mencapai standard minimum iaitu daripada 7\% pada tahun 1999 kepada 35\% pada tahun 2011. Penguasaan mata pelajaran Matematik antara langkah penting di dalam memperbaiki kedudukan Malaysia dalam kedudukan PISA. Isi kandungan mata pelajaran Matematik adalah berfokuskan kepada pengetahuan KBKK yang perlu dikuasai oleh setiap pelajar. Kemahiran berfikir kritis dan kreatif (KBKK) Matematik yang telah dikenal pasti oleh Poh (2000) meliputi kemahiran menyatakan masalah, menterjemah, membuat anggaran, menyusun atur, membuat gambarajah, memproses mental, mentafsir, mengelas, membuat perhubungan, mengecamkan pola, membuat inferens, membuat generalisasi dan membanding beza. Dalam kajian ini, KBKK yang digunakan adalah berdasarkan KBKK yang dikenal pasti oleh Pusat Perkembangan Kurikulum, Kementerian Pendidikan Malaysia (KPM, 2002).

Dalam menguasai KBKK bagi topik Integer Tingkatan 1, wujud salah faham konsep di dalam melakukan operasi yang melibatkan integer. Adalah penting untuk pelajar menentukan yang mana konsep yang betul bagi mengelakkan mereka membina pemahaman, kesimpulan, proses dan generalisasi yang salah. Proses pemahaman mereka perlu dibimbing secara terarah kearah proses penemuan dan penyelesaian masalah yang betul (Brumbaugh \& Rock, 2006). Perbezaan dalam pemahaman pelajar dan pengajaran guru ini menyebabkan proses $\mathrm{P} \& \mathrm{P}$ tidak berkesan kerana maklumat yang ingin disampaikan adalah bercanggah disebabkan salah faham yang wujud di antara guru dengan pelajar. Permasalahan ini berlaku dalam kalangan majoriti pelajar sekarang. Pelbagai pihak telah mengenal pasti permasalahan pelajar menguasai KBKK terutamanya dalam topik Integer Matematik Tingkatan 1 (Vlassis, 2004; Gullick, 2012). Pelajar secara umumnya kurang memahami dan lemah dalam konsep serta penguasaan kemahiran yang diperlukan dalam mempelajari topik Integer. Satu analisis awal telah dilakukan terhadap 120 orang pelajar tingkatan 1 yang telah 
mempelajari topik Integer untuk mengkaji dan menganalisis tahap pencapaian mengikut KBKK pelajar semasa menggunakan ujian subjektif. Pelajar 'sangat lemah' dan 'lemah' dalam kebanyakan topik. Kelemahan ketara pelajar adalah dalam sub topik penyelesaian masalah melibatkan penambahan dan penolakan integer yang mencatatkan peratusan 'sangat lemah' yang tinggi. Permasalahan ini disebabkan oleh kemahiran asas teknik penyelesaian nombor negatif dalam kalangan pelajar adalah rendah dan perlu diberi perhatian sewajarnya. Menurut Gullick (2012), pemahaman nombor negatif memerlukan pelajar menerima nilai kurang daripada 0 (yang sukar dilihat secara fizikal) yang menyebabkannya suatu konsep Matematik yang abstrak. Ini kerana minda pelajar telah ditanam dengan konsep nilai nombor positif selama enam tahun di sekolah rendah. Ini menyebabkan perbandingan bagi nilai integer negatif adalah sukar. Kajian Vlassis (2004) terhadap pengenalan integer negatif dalam kalangan pelajar mendapati pelajar perlu mengasimilasikan dan mengadaptasikan nombor negatif dalam skema pemikiran mereka tentang nombor dan ini mengelirukan pelajar.

\section{OBJEKTIF KAJIAN}

Objektif kertas kerja ini adalah untuk;

a) Mengkaji prinsip animasi exaggeration yang sesuai untuk diaplikasikan dalam topik Integer Matematik Tingkatan 1.

b) Mengkaji KBKK yang perlu dikuasai dalam topik Integer Matematik Tingkatan 1.

c) Mengkaji elemen motivasi yang sesuai untuk diaplikasikan dalam topik Integer Matematik Tingkatan 1.

d) Mencadangkan kerangka konseptual pembangunan perisian berasaskan aplikasi prinsip animasi exaggeration, KBKK dan elemen motivasi bagi topik Integer Matematik Tingkatan 1.

\section{RASIONAL KAJIAN}

Kertas kerja ini bertujuan mengenal pasti penggunaan prinsip animasi yang bersesuaian dalam kaedah pembelajaran integer bagi digunakan oleh pelajar dengan pencapaian yang berbeza dalam mempelajari topik Integer. Ia dapat membantu pelajar menguasai KBKK yang diperlukan oleh pelajar dalam mempelajari topik Integer. Pelajar dilatih dalam menggunakan KBKK yang diperlukan bagi menguasai topik. Bagi pelajar yang lemah dalam menguasai KBKK yang tertentu, pelajar digalakkan memperbaiki dan meningkatkan latihan dalam KBKK tersebut. Ini juga menggalakkan pelajar berfikir secara kritis dan kreatif. Pelajar berpeluang mempraktikkan penggunaan KBKK dalam pembelajaran berbantukan komputer dan seterusnya menguasai KBKK dengan baik dan berkesan. Pelajar dilatih menjadi kritis dan kreatif seterusnya dapat meningkatkan prestasi pelajar. Kertas kerja ini juga mengupas faktor motivasi. Motivasi merupakan faktor penting dalam memastikan proses $\mathrm{P} \& \mathrm{P}$ berkesan. Motivasi membantu meningkatkan minat dan sikap positif pelajar terhadap pembelajaran. Faktor-faktor motivasi berdasarkan model motivasi ARCS diaplikasikan dalam merangka kerangka pembangunan perisian berasaskan aplikasi prinsip animasi exaggeration 
dan KBKK bagi topik Integer Matematik Tingkatan 1. Aplikasi prinsip animasi exaggeration dan KBKK terhadap motivasi serta pencapaian pelajar turut diperincikan. Hasil penyelidikan dapat digunakan oleh guru Matematik dalam proses P\&P seharian. Kajian ini juga dapat dijadikan rujukan Kementerian Pendidikan, Institusi Pengajian Tinggi dan Bahagian Teknologi Pendidikan dalam merangka strategi pembelajaran yang selari dengan penggunaan teknologi maklumat. Kajian ini juga boleh dijadikan rujukan penyelidik lain dalam mengkaji penggunaan animasi dan KBKK dalam P\&P berbantukan komputer serta pembangunan perisian pada masa hadapan.

\section{METODOLOGI}

\section{Tinjauan Literatur}

\section{Animasi}

Animasi mula dihasilkan secara lukisan tangan yang disusun dalam bentuk berturutan yang dikenali sebagai animasi celluloid. Animasi digital hanya bermula dalam tahun 1970an di mana juru animasi mula menghasilkan animasi berdasarkan pergerakan sebenar manusia untuk menghasilkan animasi yang realistik. Dalam penghasilan animasi digital, industri animasi dipelopori oleh studio Walt Disney. Walt Disney mengaplikasikan 12 prinsip asas animasi yang dibangunkan oleh sembilan juru animasi di studio Walt Disney. Ini berdasarkan kepada pengalaman mereka dan kaedah yang digunakan bagi menghasilkan animasi yang hampir kepada objek hidup yang sebenar. 12 prinsip tersebut adalah squash and stretch, anticipation, staging, straight ahead action and pose to pose animation, follow through and overlapping action, slow in and slow out, arcs, secondary action, timing, exaggeration, weight dan appeal (Thomas \& Johnston, 1995).

\section{Prinsip Exaggeration dalam Animasi}

Kajian ini memanipulasikan kelebihan prinsip exaggeration dalam memberikan penegasan kepada kaedah pembelajaran topik Integer. Exaggeration membawa maksud jika karakter itu dalam keadaan sedih, jadikannya lebih sedih dan jika karakter itu gembira, jadikannya lebih gembira (Thomas \& Johnston, 1995). Penggunaan exaggeration yang baik dapat menghasilkan animasi yang realistik dan menarik perhatian. Hanya elemen yang paling penting perlu diaplikasikan prinsip exaggeration. Prinsip exaggeration boleh diaplikasikan ke atas elemen pergerakan, ekspresi muka, squash and stretch, lantunan atau sela masa. Dengan mengaplikasikan salah satu daripada elemen ini pembangun akan dapat menarik perhatian pengguna dan memastikan tiada maklumat yang tertinggal. Prinsip exaggeration digunakan untuk memberikan penegasan kepada sesuatu idea atau aksi. Exaggeration juga dianggap sebagai satu pergerakan melampau atau berlebih-lebih bertujuan menarik minat penonton. Exaggeration perlu dibuat terhadap pergerakan bagi memastikan penonton memberikan tumpuan kepada isi kandungan yang ingin disampaikan. Ia sesuai digabungkan dengan prinsip anticipation dan staging bagi menarik minat penonton melihat animasi yang sepatutnya menjadi tumpuan. Exaggeration akan memberikan penegasan kepada animasi dan membolehkan penonton sedar akan isu utama yang diketengahkan. Kegunaan prinsip exaggeration sepatutnya tidak menjadi 
gangguan kepada paparan tetapi lebih kepada memastikan penonton tertarik kepada animasi. Sebagai contoh, animasi lompatan seekor kanggaru boleh dibuat secara biasa atau secara berlebihan menggunakan prinsip exaggeration yang tentunya akan menarik perhatian penonton.

Exaggeration boleh dilakukan terhadap animasi dalam kadar yang sedikit atau banyak. Ia boleh dilakukan dengan mempercepatkan beberapa sela masa bagi aksi sesuatu animasi atau menjadikan karakter menjadi sepenuhnya termampat sebelum aksi satu lompatan. Ia juga bergantung kepada sesuatu aksi itu iaitu jika ia bersifat realistik sepenuhnya, ia tidak memerlukan exaggeration yang banyak. Selain daripada itu, bagi memastikan aplikasi exaggeration dalam animasi disedari dan diberi perhatian oleh pelajar, kadar exaggeration bagi sesuatu animasi perlu lebih daripada 2 sela masa. Ini memberikan masa yang secukupnya kepada pelajar untuk memberi perhatian terhadap prinsip animasi exaggeration yang dihasilkan. Menurut Kwon dan Lee (2011) dalam Cartoon-like stylization for character animation, prinsip exaggeration dalam animasi boleh diaplikasikan melalui tiga kaedah ubahsuai terhadap tiga daripada 12 prinsip animasi Walt Disney iaitu exaggeration menggunakan sub-joint hierarchy, slow in and slow out filter dan squash and stretch stylization. Prinsip exaggeration dalam animasi juga boleh diaplikasikan terhadap animasi melalui prinsip animasi Walt Disney itu sendiri melalui bahasa badan, squash and stretch, anticipation dan reka bentuk karakter.

\section{Aplikasi Prinsip Exaggeration}

\section{a) Prinsip Exaggeration melalui Bahasa Badan}

Salah satu cara untuk mengaplikasikan prinsip exaggeration dalam animasi adalah dengan melebihkan bahasa badan sesuatu karakter. Bahasa badan boleh memberikan maksud yang signifikan terhadap emosi sesuatu karakter lebih daripada dialog (Hook, 2003). Oleh itu ekspresi sesuatu watak perlu dizahirkan melalui bahasa badan selain daripada muka dan aplikasi prinsip exaggeration dalam animasi dapat melaksanakannya (Thomas \& Johnston, 1995). Sebagai contoh satu karakter yang mempunyai lebihan berat berbanding bentuk asal karakter tersebut dapat dihasilkan menggunakan bahasa badan seperti susah untuk bergerak. Bagi menghasikan suatu watak yang menggunakan aplikasi exaggeration melalui bahasa badan, pembangun animasi perlu membina karakter yang normal terlebih dahulu. Setelah selesai, barulah elemen exaggeration dikenakan ke atas watak tersebut seperti memanjangkan tangan dan kaki atau menambah berat badan ke atas watak. Ini akan menarik perhatian penonton berbanding watak yang tidak mengaplikasikan prinsip animasi exaggeration.

Aplikasi prinsip exaggeration menggunakan bahasa badan dapat diperhatikan melalui filem Aladdin (Clement \& Muser, 1992) di mana emosi ditunjukkan melalui bahasa badan oleh Magic Carpet kerana permaidani tidak mempunyai paparan muka. Exaggeration hanya bergantung kepada bahasa badan dan pergerakan secara sepenuhnya yang menghasilkan emosi karakter sedih dan gembira. Aplikasi prinsip exaggeration dalam animasi melalui bahasa badan dan pergerakan membolehkan pembangun animasi menyampaikan apa yang ingin disampikan kepada penonton sama ada secara emosi atau fizikal. Melalui aplikasi prinsip exaggeration ini kepentingan sesuatu pergerakan atau jujukan pergerakan dapat disampaikan kepada penonton dan membolehkan penonton memahami isi 
kandungan dan konsep sebenar yang ingin disampaikan di sebalik prinsip exaggeration yang diaplikasikan.

\section{b) Prinsip Exaggeration melalui Squash and Stretch}

Squash and stretch adalah satu proses yang mengubah bentuk objek yang menunjukkan kesan daya terhadap pergerakan. Apabila prinsip animasi exaggeration dikenakan terhadap daya yang dihasilkan oleh sesuatu pergerakan, ia akan menghasilkan suatu kesan yang lebih besar dan menarik minat penonton. Di dalam animasi kartun Rabid Rider (Matthew, 2010), prinsip exaggeration dalam animasi Road Runner digunakan dengan memaparkan leher yang panjang dan kaki ketinggalan di belakang apabila Road Runner mula memecut yang menunjukkan kelajuannya dan kesan kekuatan graviti. Selain daripada itu animasi Wile E Coyote juga menunjukkan aplikasi exaggeration terhadap squash and stretch dalam animasi di mana apabila jatuh dari suatu ketinggian yang ekstrem, jarak ketinggian dan daya hentaman yang terhasil menyebabkan objek meleper di atas tanah. Ini dapat menunjukkan kesan daya terhadap hentaman objek. Rajah 1 menunjukkan prinsip exaggeration squash and stretch.

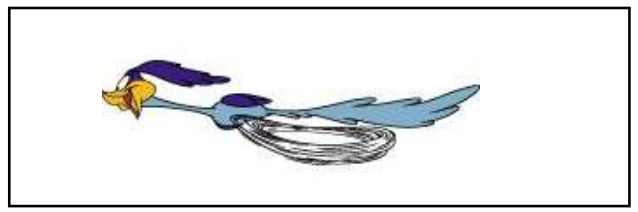

Rajah 1: Exaggeration squash and stretch.

\section{c) Prinsip Exaggeration melalui Anticipation}

Anticipation membolehkan penonton menjangka pergerakan lanjutan daripada sesuatu aksi. Biasanya pergerakan anticipation akan terjadi pada arah yang bertentangan dengan arah gerakan asal. Aplikasi prinsip exaggeration dalam anticipation membolehkan sesuatu animasi itu mendapat perhatian lebih lama (Maestri, 2006). Aplikasi exaggeration dalam anticipation juga boleh dilakukan di awal animasi yang membolehkan penonton menjangka apa yang karakter animasi akan lakukan.

\section{d) Prinsip Exaggeration dalam Reka Bentuk Karakter}

Aplikasi prinsip exaggeration dalam mereka bentuk suatu karakter akan menghasilkan suatu watak yang mempunyai ciri istimewanya yang tersendiri. Karakter lelaki gemuk boleh diubah suai menjadi lebih gemuk melalui exaggeration dan ini menghasilan suatu watak yang mempunyai penegasan terhadap cirinya yang tersendiri. Reka bentuk seorang lelaki gemuk adalah biasa dan tidak mempunyai sebarang ciri istimewa yang dapat menarik minat penonton. Sebaliknya apabila prinsip exaggeration digunakan, lelaki gemuk digambarkan sebagai obes yang lebih mendatangkan kesan terhadap penonton (Hedgpet \& Missal, 2003). Aplikasi exaggeration terhadap reka bentuk karakter ini memberikan kesan yang lebih mendalam terhadap penonton. Rajah 2 menunjukkan exaggeration dalam reka bentuk karakter. 


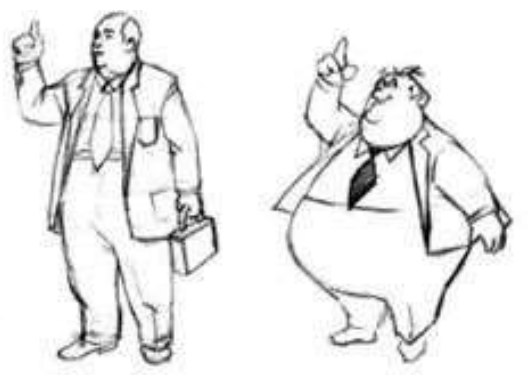

Rajah 2: Exaggeration dalam reka bentuk karakter.

\section{Aplikasi Prinsip Exaggeration dalam Kajian}

Aplikasi prinsip exaggeration yang digunakan dalam kajian ini adalah kombinasi exaggeration squash and stretch dan exaggeration reka bentuk karakter. Kaedah ini digunapakai dalam kajian ini kerana ia bersesuaian dengan keperluan kajian. Dalam kajian ini, watak seekor kanggaru dikenakan exaggeration terhadap reka bentuk karakternya dengan membesarkan bahagian kepala melebihi daripada saiz normal. Selain daripada itu kanggaru tersebut turut dimanipulasikan pergerakannya menggunakan prinsip exaggeration kaedah squash and stretch pada garis nombor bagi memberi penekanan kepada isi kandungan konsep yang ingin disampaikan. Konsep penambahan integer menunjukan seekor kanggaru dikenakan prinsip exaggeration reka bentuk karakter dan exaggeration pergerakannya melalui squash and stretch di dalam pergerakannya di atas garis nombor menghala ke arah kanan. Sementara itu bagi konsep penolakan integer, seekor kanggaru dikenakan dengan prinsip exaggeration reka bentuk karakter dan exaggeration pergerakannya melalui squash and stretch di dalam pergerakannya di atas garis nombor menghala ke arah kiri. Rajah 3 menunjukkan aplikasi prinsip animasi exaggeration dalam kajian.

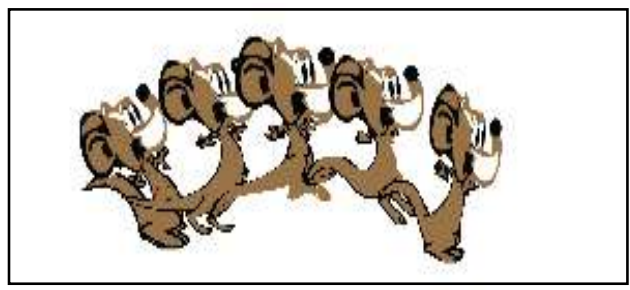

Rajah 3: Aplikasi prinsip animasi exaggeration dalam kajian.

Prinsip exaggeration dibuat terhadap reka bentuk karakter terhadap kepala kanggaru dan kemudiannya menggunakan pendekatan exaggeration melalui squash and stretch terhadap pergerakan kanggaru yang dapat dilihat dalam pergerakan awal lompatan, di pertengahan lompatan dan semasa mendarat. Aplikasi squash and stretch ini memberikan kesan exaggeration terhadap pergerakan apabila dianimasikan. Pengaplikasian prinsip exaggeration melalui reka bentuk karakter dan squash and stretch terhadap pergerakan kanggaru di atas garis nombor dapat menarik minat 
pelajar untuk menumpukan perhatian terhadap konsep penambahan integer dan penolakan integer di atas garis nombor. Konsep ini seterusnya akan menjadi asas kepada pembelajaran topik Integer Matematik Tingkatan 1.

\section{Kepentingan Prinsip Exaggeration}

Penggunaan prinsip exaggeration yang berkesan bergantung kepada idea yang ingin disampaikan. Pemahaman terhadap idea yang ingin disampaikan melalui exaggeration membolehkan pengguna turut memahami idea tersebut. Walau bagaimanapun, aplikasi prinsip exaggeration perlu dibuat secara berhati-hati dan seimbang. Tidak semua aksi, reka bentuk, objek dan emosi perlu menggunakan prinsip exaggeration. Ini bagi mengelakkan hasil yang tidak realistik. Keseimbangan perlu diwujudkan bagi memastikan pengguna dapat memahami idea yang ingin disampaikan dan animasi yang dihasilkan adalah realistik (Lasseter, 1987). Exaggeration adalah satu kaedah bagi memberi penekanan kepada sesuatu bertujuan untuk menunjukkan kepentingannya atau untuk menarik perhatian. Dengan mengaplikasikan exaggeration pada elemen yang tepat, pembangun animasi dapat memberi panduan kepada pengguna untuk mengenal pasti idea dan mesej yang ingin disampaikan melalui animasi yang dihasilkan. Tanpa exaggeration animasi akan menjadi bosan dan tidak realistik. Pergerakan biasa tidak menarik minat. Oleh yang demikian, pergerakan yang menggunakan aplikasi prinisip exaggeration animasi dibuat supaya lebih menarik minat dan seronok untuk dilihat. Asas kepada aplikasi prinsip animasi exaggeration adalah menjadikan sesuatu animasi tersebut lebih ekstrem tetapi pada masa yang sama tidak keterlaluan yang boleh menyebabkan animasi menjadi tidak logik. Oleh itu, aplikasi prinsip exaggeration yang tepat penting supaya dapat memberi penekanan dan menarik perhatian pelajar.

\section{KEMAHIRAN BERFIKIR KRITIS DAN KREATIF (KBKK)}

\section{Definisi KBKK}

Kemahiran berfikir secara kritis dan kreatif mempunyai banyak definasi yang berbeza dan komponen yang pelbagai. Menurut Peg (2011), KBKK adalah berfikir secara mendalam untuk menilai sesuatu perkara dan memutuskan sama ada menerima atau menolaknya. Ia bukan sekadar menerima sesuatu perkara tetapi memahami, menganalisis dan menilai situasi serta sebarang kemungkinan hasil daripada sebarang keputusan sebelum membuat keputusan menerima atau menolaknya. Menurut Paul dan Elder (2006), kemahiran berfikir kritis adalah kemahiran mengkaji maklumat, situasi dan fakta secara mendalam. Ia melibatkan mengumpul, menganalisis, menguji dan menilai sesuatu maklumat. Ia juga dapat membezakan di antara fakta dan pendapat. Sementara itu kemahiran berfikir kreatif pula adalah kemahiran menggunakan imaginasi dan sumbangsaran di dalam membangunkan penyelesaian, mencari alternatif dan melihat dari perspektif yang berbeza (Paul \& Elder, 2006). KBKK turut melibatkan metakognisi. Apabila pelajar berfikir secara kritis tentang sesuatu topik yang dipelajari, mereka menggunakan metakognisi. Pelajar yang menggunakan metakognisi bukan sahaja menggaplikasikan apa yang dipelajari malahan turut berfikir tentang bagaimana mereka berfikir. Ini merupakan tanda aras kejayaan pendidikan (Szabo \& Schwartz, 2011). Menurut Nickerson (2008), KBKK diaplikasikan secara rasional. Ia merupakan cara berfikir yang menggunakan prinsip rasional. 
KBKK adalah satu kemahiran yang secara konsepnya boleh dipelajari, dilatih dan diamalkan dalam kehidupan seharian

\section{Model KBKK}

Model KBKK utama yang digunakan dalam kajian ini adalah model KBKK KPM (KPM, 2002). Model KBKK KPM ini menggariskan kemahiran-kemahiran berfikir kreatif dan kritis yang perlu dikuasai oleh pelajar. Model KBKK ini telah dibina dan disusun mengikut hierarki daripada kemahiran asas kepada kemahiran yang lebih kompleks. Kemahiran-kemahiran berfikir kritis dan kreatif yang perlu dikuasai oleh pelajar adalah bergantung kepada tajuk dan topik yang perlu dipelajari. Topik yang berbeza memerlukan pelajar menguasai kemahiran berfikir kritis dan kreatif yang berbeza. Dalam proses pengajaran dan pembelajaran, kemahiran berfikir diajar mengikut urutan. Pelajar perlu belajar dan menguasai kemahiran berfikir yang asas sebelum mempelajari kemahiran berfikir yang lebih kompleks.

Kemahiran berfikir kreatif adalah menjanakan idea, menghubungkaitkan, membuat inferens, membuat hipotesis, mensintesiskan, mengitlak dan membuat gambaran mental. Kemahiran berfikir kritis pula adalah mencirikan, membandingkan dan membezakan, mengumpul dan mengelaskan, membuat urutan, menyusun mengikut keutamaan, menganalisis, mengesan kecondongan, menilai dan membuat kesimpulan. Sekiranya sesuatu tajuk memerlukan pelajar menguasai kemahiran berfikir kreatif membuat hipotesis, pelajar sepatutnya telah menguasai kemahiran berfikir menjanakan idea, menghubungkaitkan dan membuat inferens. Walaubagaimanapun, kemahiran-kemahiran berfikir yang perlu dikuasai oleh pelajar adalah tertakluk kepada tajuk dan topik yang perlu dikuasai oleh pelajar. Tidak semua KBKK bersesuaian untuk setiap topik. Oleh yang demikian, KBKK yang perlu dikuasai oleh pelajar ditentukan sebelum pelajar mempelajari topik tersebut.

\section{Aplikasi Model KBKK dalam Kajian}

Dalam kajian ini, KBKK yang perlu dikuasai oleh pelajar dalam topik Integer disusun kandungannya mengikut sub topik yang telah ditetapkan. Pelajar membina pengetahuan tentang sesuatu kemahiran contohnya kemahiran membuat urutan melalui contoh yang diberi dan kemudiannya diikuti dengan soalan penyelesaian masalah atau situasi yang menguji penguasaan pelajar terhadap KBKK membuat urutan. Seterusnya pelajar kemudiannya diberikan dengan situasi baharu bagi mengaplikasikan kemahiran membuat urutan. Ia akan memastikan kemahiran tersebut dapat dikuasai sepenuhnya oleh pelajar melalui pengulangan kitaran ini. Kemahiran berfikir kritis yang perlu dikuasai oleh pelajar adalah membanding dan membezakan, membuat urutan dan menganalisis manakala kemahiran berfikir kreatif yang perlu dikuasai adalah membuat gambaran mental. Kemahiran berfikir kritis membanding dan membezakan melibatkan hasil pembelajaran membaca dan menulis integer, membandingkan nilai dua integer serta penyelesaian masalah melibatkan penambahan integer dan penyelesaian masalah melibatkan penolakan integer. Kemahiran berfikir kritis membuat urutan melibatkan hasil pembelajaran mewakilkan integer pada garis nombor dan menyusun integer dalam urutan. Kemahiran berfikir kritis menganalisis melibatkan hasil pembelajaran menulis nombor positif dan nombor negatif untuk mewakilkan kata huraian. Kemahiran berfikir kreatif membuat gambaran mental pula melibatkan hasil pembelajaran menambah integer dan menolak integer. Hasil-hasil 
pembelajaran ini perlu dikuasai bagi membolehkan pelajar menguasai KBKK yang ditetapkan dalam topik Integer Matematik Tingkatan 1.

\section{MODEL MOTIVASI}

Motivasi adalah komponen penting dalam proses pengajaran dan pembelajaran. Kajian membuktikan motivasi memberikan kesan kepada hasil pembelajaran kerana ia merupakan faktor utama yang mendorong kepada pencapaian akademik pelajar. Beberapa teori yang menerangkan tentang faktor motivasi dalam bahan instruksional telah dikenal pasti termasuklah dua model yang terkenal iaitu model motivasi ARCS (Keller, 1987) dan model motivasi intrinsik (Malone \& Lepper, 1988). Model motivasi ARCS mempunyai empat komponen iaitu menarik perhatian (attention), kerelevanan (relevance), keyakinan (confident) dan kepuasan hati (satisfaction). Model motivasi intrinsik mempunyai empat faktor iaitu cabaran (challenge), rasa ingin tahu (curiosity), kawalan (control) dan fantasi (fantasy). Kedua-dua model mempunyai beberapa persamaan seperti dinyatakan oleh Bixler (2006).

\section{Model Motivasi ARCS}

Model motivasi ARCS dipilih kerana ia amat sesuai digunakan dalam mereka bentuk, membangunkan dan menilai bahan instruksional. Model ARCS berfokus kepada bahan pembelajaran instruksional dan direka bentuk untuk menilai keberkesanan pembelajaran di dalam kelas (Kim, 2005). Model ARCS ini digunapakai secara meluas dalam menghasilkan bahan instruksional kerana ia dapat menghubungkan teori motivasi pembelajaran, reka bentuk instruksional dan proses pembangunan (Huang \& Johnson, 2002). Model motivasi ARCS telah dibangunkan Keller [25] yang merupakan satu kaedah bagi meningkatkan motivasi pelajar terutamanya terhadap bahan instruksional. Model ARCS dibangunkan berasaskan teori makro motivasi dan reka bentuk berarah (Instructional Design) (Keller, 1983; 1987). Model ini berfokus kepada mencipta, mensimulasi dan mengekalkan persekitaran motivasi dalam pembelajaran pelajar. Model ini berasaskan kepada teori nilai jangkaan hasil yang mengatakan pelajar akan bermotivasi untuk melibatkan diri dalam aktiviti atau tugasan jika mereka berpuas hati terhadap nilai sesuatu tugasan dan pelajar yakin dapat menyelesaikan tugasan yang diberikan. Oleh yang demikian, aktiviti yang dirancang untuk pelajar perlu bermakna dan memberikan rangsangan positif bahawa pelajar akan dapat menyelesaikannya.

\section{Elemen Model ARCS}

Keller mencadangkan bahawa motivasi dalam pembelajaran dipengaruhi oleh empat komponen persepsi utama. Empat komponen dalam model motivasi ARCS (Keller, 1983; 1987) adalah;

(a) Menarik perhatian (Attention, A) - menarik minat dan mengekalkan perhatian pelajar dan rasa ingin tahu kepada bahan pembelajaran.

(b) Kerelevanan (Relevance, R) - menghubungkan objektif pembelajaran, minat pelajar, motif dan kegunaan pembelajaran pada masa hadapan.

(c) Keyakinan (Confident, C) - membina keyakinan dalam pembelajaran serta kemampuan menyelesaikan aktiviti dan tugasan. 
(d) Kepuasan (Satisfaction, S) - mewujudkan kepuasan pembelajaran secara ekstrinsik dan intrisik kepada pelajar apabila berjaya menyelesaikan tugasan

\section{KEPUTUSAN DAN PERBINCANGAN}

\section{Aplikasi Prinsip Exaggeration Animasi, KBKK dan Motivasi dalam Kajian}

Strategi yang digunakan dalam pembangunan animasi ini adalah mengaplikasikan prinsip exaggeration dalam animasi yang dihasilkan. Animasi yang dikenakan prinsip exaggeration ini dihasilkan ke atas KBKK yang perlu dikuasai oleh pelajar. Sebagai contoh pelajar perlu menguasai KBKK membanding dan membezakan. Animasi dengan aplikasi prinsip exaggeration dihasilkan bagi membolehkan pelajar menguasai hasil pembelajaran membaca dan menulis integer manakala membandingkan nilai dua integer pula merupakan hasil pembelajaran bagi KBKK membanding dan membezakan. Penguasaan kedua-dua hasil pembelajaran melalui animasi yang dihasilkan membolehkan pelajar menguasai KBKK membanding dan membezakan. Penguasaan KBKK ini membolehkan peningkatan pencapaian pelajar kerana pelajar dapat menjawab soalan berbentuk KBKK. Animasi yang dapat menarik perhatian pelajar akan memotivasikan pelajar untuk menjelajah bagi mencari maklumat dan membina pengetahuan baharu daripada pengetahuan sedia ada pelajar. Melalui proses memahami konsep dengan melakukan sendiri aktiviti, pelajar akan dapat mengawal proses pembelajaran dengan kadar pemahaman mereka sendiri.

Kerelevanan adalah elemen di mana pelajar akan mengenal pasti sejauh mana bahan pembelajaran itu penting dan mengapa ia penting. Ini dapat dikaitkan dengan objektif pembelajaran dan kegunaan hasil pembelajaran pada masa hadapan. Setelah pelajar memberikan fokus terhadap konsep yang perlu difahami dan KBKK yang perlu dikuasai melalui exaggeration, pelajar dapat mengetahui kepentingan hasil pembelajaran yang dipelajari. Kesedaran kepentingan menguasai KBKK ini mampu memberikan kesan positif terhadap pencapaian pelajar kerana pelajar akan berusaha menjawab soalan KBKK yang diberikan. Kerelevanan membantu pelajar menghubungkait pengalaman pembelajaran pelajar dengan bahan pembelajaran instruksional yang digunakan. Ini membolehkan pelajar memahami kepentingan mempelajari kemahiran yang perlu dikuasai untuk diaplikasikan dalam tugasan lain pada masa hadapan. Strategi yang digunakan adalah animasi yang dihasilkan daripada realiti dan persekitaran pelajar. Ini membolehkan pelajar mudah memahami kerelevanan dan kepentingan menguasai kandungan pembelajaran yang disediakan.

Keyakinan adalah elemen ketiga dalam model ARCS. Exaggeration memberi penekanan untuk menarik perhatian pelajar memahami konsep dan mengenal pasti KBKK yang perlu dikuasai seterusnya membina kerelevanan dalam diri pelajar menguasai hasil pembelajaran. Ini membina keyakinan bahawa pelajar dapat menjawab soalan yang dikemukakan. Keyakinan ini ditanam dalam diri pelajar di awal proses pembelajaran kerana ia dapat memberikan kesan positif terhadap kesungguhan pelajar bagi menyelesaikan permasalahan seterusnya mencapai objektif pembelajaran. Pembelajaran yang bermakna membantu membina keyakinan pelajar semasa proses pembelajaran. Sikap positif ini secara langsung akan membantu meningkatkan pencapaian pelajar apabila pelajar mempunyai keyakinan tinggi dalam menjawab soalan berbentuk KBKK. Strategi penting dalam 
membina keyakinan dalam kalangan pelajar adalah kawalan pelajar terhadap aktiviti pembelajaran. Kekerapan dalam memberikan maklum balas terhadap jawapan pelajar serta pembayang kepada soalan akan membantu pelajar membina keyakinan menyelesaikan tugasan.

Kepuasan memberikan suatu peneguhan positif terhadap usaha pelajar dalam menyelesaikan sesuatu tugasan. Exaggeration menarik perhatian pelajar, menjana kerelevanan dalam diri pelajar dan membina keyakinan untuk menguasai KBKK yang telah ditetapkan. Kejayaan mencapai objektif yang disasarkan akan meningkatkan pencapaian pelajar seterusnya memberikan kepuasan kepada pelajar. Pelajar juga diberikan ganjaran ekstrinsik yang seterusnya akan menjana motivasi dalaman pelajar. Kepuasan akan wujud apabila pelajar dapat mengunakan kemahiran atau pengetahuan yang baharu dipelajari bagi menyelesaikan tugasan dan menerima maklum balas yang dapat menjana sikap positif terhadap tugasan. Ini juga dapat memberikan peneguhan kepada pelajar untuk mengekalkan konsistensi pembelajaran yang diinginkan (Keller, 1983). Strategi memberikan kata-kata semangat, ganjaran apabila mendapat jawapan yang betul dan kata-kata pujian dapat meningkatkan kepuasan pelajar. Pelajar gembira sepanjang proses pembelajaran. Kemampuan pelajar membina pengetahuan baharu di akhir sesi pembelajaran merupakan motivasi utama dalam memberikan kepuasan kepada pelajar.

Faktor-faktor motivasi ARCS perlu dikekalkan setiap masa kerana jika ia gagal untuk diaplikasikan, motivasi pelajar akan hilang dan objektif pembelajaran tidak akan tercapai. Pelajar yang bermotivasi akan berusaha gigih dan memberikan komitmen tinggi dalam pembelajarannya. Ini seterusnya akan memberikan impak positif terhadap pencapaian pelajar.

\section{Kerangka Konseptual Kajian}

Kerangka konseptual kajian dibangunkan berasaskan kajian terperinci terhadap animasi, KBKK dan model motivasi yang sesuai dalam topik Integer Matematik Tingkatan 1. Bagi tujuan menganimasikan kaedah pembelajaran garis nombor integer Matematik ini, 12 prinsip asas animasi Walt Disney (Thomas \& Johnstron, 1995) telah diperincikan. Kajian memfokuskan kepada salah satu prinsip animasi iaitu exaggeration. Prinsip exaggeration dimanipulasikan dalam reka bentuk karakter dan pergerakan objek menggunakan kaedah pembelajaran garis nombor. Pengaplikasian prinsip animasi exaggeration ini selari dengan penggunaan model motivasi ARCS dalam pembangunan perisian serta kajian sikap pelajar terhadap motivasi. Elemen-elemen ARCS seperti menarik perhatian, kerelevanan, keyakinan dan kepuasan ini diserapkan dalam perisian.

Modul perisian mengambil kira KBKK, kaedah pembelajaran garis nombor dan prinsip exaggeration dalam animasi. Modul terdiri daripada modul Pengenalan, modul Eksplorasi, modul Penambahan, modul Penolakan, modul Latihan dan modul Tip@Petua. Setiap modul ini mengandungi ciri KBKK, kaedah garis nombor dan aplikasi prinsip animasi exaggeration. Modul-modul ini merangkumi subtopik yang perlu dikuasai oleh pelajar dalam topik Integer Matematik Tingkatan 1. 


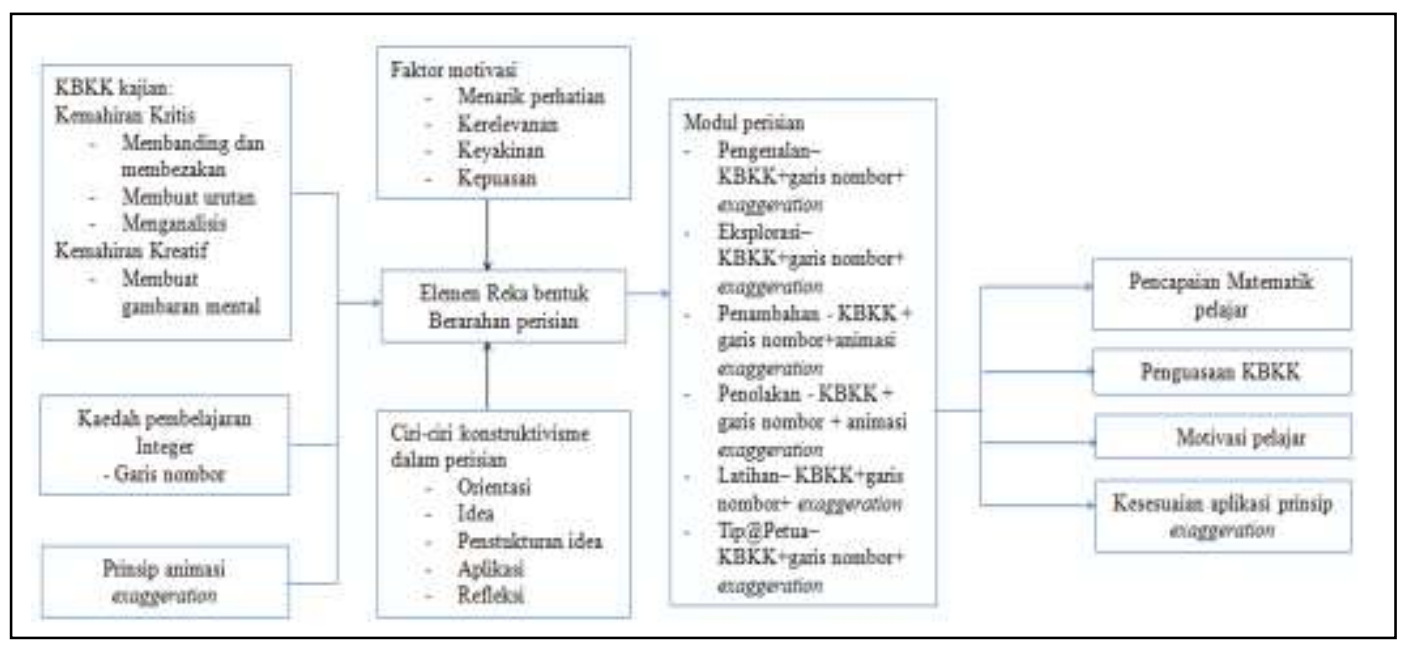

Rajah 4: Kerangka Konseptual Kajian

\section{KESIMPULAN}

Kertas kerja ini menerangkan tentang prinsip animasi exaggeration, KBKK, model motivasi ARCS dan mengaplikasikannya ke dalam pembelajaran topik Integer Matematik Tingkatan 1. Aplikasi prinsip exaggeration yang digunakan dalam kajian ini adalah kombinasi exaggeration squash and stretch dan exaggeration reka bentuk karakter yang dapat dilihat menerusi pergerakan kanggaru di atas garis nombor. Aplikasi kemahiran berfikir kritis yang perlu dikuasai oleh pelajar pula adalah membanding dan membezakan, membuat urutan dan menganalisis manakala kemahiran berfikir kreatif yang perlu dikuasai adalah membuat gambaran mental. Aplikasi ini melibatkan hasil pembelajaran membaca dan menulis integer, membandingkan nilai dua integer serta penyelesaian masalah melibatkan penambahan integer dan penyelesaian masalah melibatkan penolakan integer. Manakala bagi elemen motivasi, keempat-empat elemen motivasi ARCS iaitu menarik perhatian, kerelevanan, keyakinan dan kepuasan adalah penting dalam mengekalkan motivasi pelajar terhadap topik Integer. Elemen-elemen motivasi ARCS diaplikasikan bersama-sama dengan prinsip exaggeration dan KBKK dalam topik Integer Matematik Tingkatan 1. Prinsip animasi exaggeration, KBKK dan elemen model motivasi ARCS yang telah dikenal pasti adalah merupakan elemen penting yang menyumbang kepada penghasilan kerangka konseptual kajian bagi kajian yang dijalankan.

\section{PENGHARGAAN}

Saya ingin mengucapkan jutaan terima kasih kepada kedua ibu bapa, isteri dan keluarga atas sokongan sepanjang saya menyiapkan kertas kerja ini. Terima kasih juga diucapkan kepada penyeliapenyelia kajian Prof. Madya Dr. Nor Hasbiah Ubaidullah dan Dr. Norasikin Fabil di atas sokongan, cadangan dan tunjuk ajar. Tidak lupa juga kepada rakan-rakan dan pelajar-pelajar yang terlibat secara langsung atau tidak langsung dalam kajian ini. 
Aplikasi Prinsip Animasi Exaggeration, Kemahiran Berfikir Kritis dan Kreatif serta Model Motivasi ARCS Terhadap Topik Integer Matematik Tingkatan Satu

\section{RUJUKAN}

Bixler, B. (2006). Motivation and its relationship to the design of educational games. Paper presented at the NMC. Cleveland, Ohio. (atas talian) http://archive.nmc.org/events/2006summerconf/materials/Bixler/m\&g.pdf (16 Mac 2012).

Brumbaugh, K., \& Rock, D. (2006). Teaching secondary Mathematics. [3rd Ed.]. Lawrence Erlbaum Assosiates:New Jersey.

Clement, R., \& Musker, J. (Pengarah), (1992). Aladdin [Filem]. USA: Disney.

Gullick, M. M. (2012). Understanding Less Than Nothing: Investigations into The Representation of Negative Numbers. Doctoral dissertation, Dartmouth College. Hanover, New Hampshire.

Hook, E. (2003). Acting for animators - A complete guide to performance animation. Revised Ed. Heinemann.

Hedgpet K. \& Missal S. (2003). Exploring Drawing for Animation: The Art and Technique for Drawing for 2D Animation. Illustrated Ed. Cengage Learning.

Huang, D. W. H., \& Johnson, T. (2002). Motivational level of a computer-based simulation: A formative evaluation of the US Army Recruiting Simulation (USAREC). Annual Proceedings. Dallas, 179.

Keller J. M. (1983). Motivational Design of Instruction. Instructional-Design Theories and Models. Hillsdale, NJ: Erlbaum.

Keller, J. M. (1987). Development and use of the ARCS model of motivational design. Journal of Instructional Development, 10(3), 2-10.

Kementerian Pendidikan Malaysia. (2002). Kemahiran Berfikir dalam Pengajaran dan Pembelajaran. Kuala Lumpur: Kementerian Pendidikan Malaysia.

Kementerian Pendidikan Malaysia (2013). Pelan Pembangunan Pendidikan Malaysia (2013-2025). Kuala Lumpur: Kementerian Pendidikan Malaysia.

Kim, J. (2005). Physicalism, or Something Near Enough. New Jersey, NJ: Princeton University Press.

Kwon, J. and Lee, I. K. (2011). Cartoon-like stylization for character animation. Ubiquitous Virtual Reality International Symposium.

Lasseter, J. (1987). Principles of Traditional Animation applied to 3D Computer Animation. ACM Computer Graphics, 21(4), $35-44$.

Malone, T. W., \& Lepper, M. R. (1988). Making learning fun: A taxonomy of intrinsic motivations for learning. In R. E. Snow and M. J. Farr (Eds.). Aptitude, learning, and Instructions 3. Cognitive and affective process analyses. (pp. 229 - 253). Hillsdale,NJ: Erlbaum.

Matthew, O. (Pengarah). (2010). Rabid Rider. USA:Warner Bros.

Maestri, G. (2006). Digital character animation 3. Illustrated revised Ed. New Riders.

Nickerson, R. S. (2008). Aspects of rationality: Reflections on what it means to be rational and whether we are. New York, NY: Psychology Press.

Paul, R., \& Elder, L. (2006). Critical Thinking: The Nature of Critical and Creative Thought. Journal of Developmental Education. 30(2). 34-35.

Peg, T. (2011). Critical Thinking: An Appeal to Reason. New York. Routledge : 1-10.

Poh, S. H. (2000). KBKK : Kemahiran Berfikir Secara Kritis Dan Kreatif. Subang Jaya, Selangor: Kumpulan Budiman Sdn. Bhd.

Szabo, Z., \& Schwartz, J. (2011). Learning methods for teacher education: The use of online discussions to improve critical thinking. Technology, Pedagogy, and Education. 20(1). 79-94.

Thomas F., \& Johnston O. (1995). The Illusion of Life: Disney Animation. Hyperion. Walt Disney Production:USA.

Vlassis, J. (2004). Making sense of the minus sign or becoming flexible in 'negativity'. Learning and Instruction. 14. 469-484. 